\title{
Effects of Ankaferd Blood Stopper on Nerve Conductance: An experimental Study on the Rat Sciatic Nerve
}

\author{
Alper AKTAS ${ }^{1}$, Nuray ER ${ }^{1}$, Mehmet A. ONUR ${ }^{2}$, Gamze TAN ${ }^{2}$, Mutlu HAYRAN ${ }^{3}$ \\ ${ }^{1}$ Hacettepe University Faculty of Dentistry Department of Oral Maxillofacial Surgery \\ ${ }^{2}$ Hacettepe University Faculty of Science Department of Biology \\ ${ }^{3}$ Hacettepe University Faculty of Medicine Department of Preventive Oncology Institute of Oncology, Ankara, TURKEY
}

\begin{abstract}
The aim of this study was to evaluate the effect of AnkaferdBloodStopper $($ (ABS) on nerve conductance. ABS consists of traditional haemostatic ingredients, and has been officially approved for topical use in the management of external hemorrhage and dental surgical procedures. The basic mechanism of action for ABS is the formation of an encapsulated protein network that provides focal points for vital erythrocyte aggregation.

Total of 6 albino rats were used for nerve conduction experiments. Isolated rat sciatic nerves were placed in two suction electrodes in a pyrex bath containing a tyrode solution. Concentration-dependent evoked compound action potentials (CAP) of the nerves were recorded for 60 minutes within the ABS solution. The readings were conducted for 60 more minutes after washing the nerves. A significant reduction cAP voltage in $1000 \mu$ test groups was recorded.

The pairwise comparisons showed that the only significant differences were between $1000 \mu \mathrm{L}$ and the rest of the solutions, but this effect was totally reversible after washing with tyrode solution at 120 min readings. No significant difference exists among groups for any other parameters. Observation of recovery of the CAPs on washed specimens, demonstrating that ABS has a reversible adverse effect on nerve conductance irrespective of the concentration applied.
\end{abstract}

Keywords: Haemostatics, Neural conduction, Sciatic nerve, Action Potentials

\section{ÖZET}

\section{Sinir Illetkenliğinde Ankaferd Blood Stopper'in Etkisi: Rat Siyatik Sinirinde Deneysel Çalışma}

Bu çalışmanın amacı Ankafer Blood Stopper'ın (ABS) sinir iletkenliği üzerine etkisinin incelenmesidir. ABS, geleneksel tıpta kullanılan bitkilerinin birleşiminden oluşmaktadır ve tıp ve dişhekimliği alanında görülen eksternal kanamaların durdurulmasında kullanılmak üzere sağlık bakanlığınca onaylanmış bir ilaçtır. ABSnin temel mekanizması canlı eritrositlerin agregasyonları için fokal noktalar sağlayacak şekilde enkapsüle protein ağ oluşturmaktır.

Sinir iletkenliği çalışması için toplam 6 albino rat kullanılmıştır. izole edilen siyatik sinirler pyrex solüsyonu bulunan banyo içine yerleştirilmiştir. izole edilen rat siyatik sinir tyrod solüsyonu içeren pyrex banyo içinde iki elektrot arasına yerleştirilmiştir. Sinirlerin, konsantrasyon bağımlı potansiyel (CAP) farkı 60 dakika boyunca ABS solüsyonu içindeyken kaydedilmiştir. Sinirler yıkandıktan sonra 60 dakika daha kayda devam edilmiştir. $1000 \mu \mathrm{l}$ test grubunda belirgin azalma kaydedilmiştir.

İkili mukayeselerde saptanan tek anlamlı fark sadece $1000 \mu \mathrm{L}$ ve diğer solüsyonlar arasında görülmüştür. Fakat bu etki sinirin tyrode solüsyonu ile yıkanması sonrası elde edilen 120. dakikada tamamen kaybolmuş ve sinir etkisi eski haline dönmüştür.Bütün gruplarda diğer parametrelerde belirgini bir fark saptanamamıştır. Yıkanmış sinirlerdeki gözlem ve kayıtlar ABS'nin doz bağımsız olarak sinir üzerine gösterdiği etkinin geri dönüşümlü olduğunu göstermiş̧ir.

Anahtar Kelimeler: Hemostatikler, Nöral iletim, Siyatik sinir, Aksiyon potansiyelleri 


\section{INTRODUCTION}

Bleeding can cause significant morbidity and mortality in any clinical setting. In most situations, extractions and other similarly invasive procedures can be managed safely in a community dental practice..$^{1-2}$ Beside this, serious problems can be encountered during and after tooth extraction procedures. Especially coagulation problems related to acquired or congenitally diathesis, comprise patients with multiple coagulapathies, advanced uremia without dialysis, platelet count of less than 50.000, preliver transplant status, aplastic anemia and high dose cancer therapy need presurgical preparations. ${ }^{1-2}$ Hemorrhage can be a major complication of routine dental treatments in patients with bleeding disorders.

Various adjuncts to haemostasis can be employed at the surgical site to enhance haemostasis but haemostatic techniques must not be used too aggressively during surgery because of a risk of tissue damage. ${ }^{3}$ Devitalized tissue and foreign bodies in a healing wound forms a good environment for bacteria and shield them from the body's defenses. The dead cells and cellular debris of necrotic tissue have been shown to reduce host immune defenses and encourage active infection. A necrotic burden allowed to persist in the wound can prolong the inflammatory response, mechanically obstruct the process of wound healing, and delay reepithelization. ${ }^{3}$ Further, since bioresorbable haemostatic materials also carry the risk of infection and may delay healing; they should be avoided in immunosupressed patients. ${ }^{4-6}$ Researches for better haemostatic agent is continuing to find fast acting and tissue friendly agents.

Ankaferd Blood Stopper ${ }^{\circledR}$ (ABS) is a proprietary herbal extract, which has historically been used in Anatolia as a traditional haemostatic agent, obtained from five different plants: Thymus vulgaris, Glycyrrhiza glabra, Vitis vinifera, Alpinia officinarum and Urtica dioica. ${ }^{7}$ The basic mechanism of action for ABS is the formation of an encapsulated protein network that provides focal points for vital erythrocyte aggregation. ABS-induced protein network formation with blood cells particularly erythrocytes covers the primary and secondary haemostatic system without disturbing individual coagulation factors. ${ }^{7}$ ABS-induced formation of the protein network covers the entire physiological haemostatic process without unequally affecting any individual clothing factor. ABS may, therefore, be effective both in individuals with normal haemostatic parameters and in patients with deficient primary and/or secondary homeostasis. ${ }^{7}$ On the basis of the safety and efficacy reports indicating its sterility and biocompatibility, ABS has been officially approved for topical use in the management of external hemorrhage and dental surgery bleedings in Turkey (www.ankaferd.com). However, little is known about the interactions of ABS with neural tissues, despite the fact that many haemostatic agents in the form of solutions may easily contact the nerve bundle through the extraction socket.

In light of these observations, the present study investigated the effect of the ABS on nerve conduction through determination of compound action potentials (cAPs) on the isolated rat sciatic nerve model. ${ }^{7-8}$

\section{MATERIALS and METHODS}

Test specimens prepared with $100 \%$ Ankaferd Blood Stopper ${ }^{\circledR}$. Solutions containing $50 \mu 1,100 \mu 1,250 \mu 1$, $500 \mu \mathrm{l}$ and $1000 \mu \mathrm{l}$ ABS prepared in Tyrode solution solution.

The experiments were conducted on 6 locally-bred Albino rats (Rattus rattus) weighing meanly $250 \mathrm{~g}$. The animals were cared for according to the policies and principles established by the Animal Welfare Act and the NIH guide for Care and Use of Laboratory Animals (publication \#86-23). Rats were anesthetized with a mixture of ketamin (Ketalar, Parke Davis NJ, USA: $30 \mathrm{mg} / \mathrm{kg} \mathrm{IM}$ ) and xylazine (Rompun, Bayer Leverkusen, Germany: $10 \mathrm{mg} / \mathrm{kg}$ IM).

Sciatic nerves were dissected from the spinal cord to the knee cleaned of adherent tissue under a surgical microscope. Thereafter, the nerves were placed in a pyrex recording bath containing three chambers (Figure 1) a perfusion chamber in the middle, and two chambers on each side containing suction electrodes for stimulation and recording cAPs. These chambers were separated by two $4 \mathrm{~mm}$-thick pyrex plates. The nerves were supported along the bath mainly by the top of the two partitioning plates and were floating in perfusion chambers. The bath containing Tyrode solution $\left(8 \mathrm{~g} / 1 \mathrm{NaCl}, 0.2 \mathrm{~g} / \mathrm{l} \mathrm{KCl}, 0.2 \mathrm{~g} / 1 \mathrm{CaCl}_{2}, 0.1 \mathrm{~g} / \mathrm{l}\right.$ $\mathrm{MgCl}_{2}, 1 \mathrm{~g} / 1 \mathrm{NaHCO} 3,0.05 \mathrm{~g} / 1 \mathrm{NaH}_{2} \mathrm{PO}_{4}, 1 \mathrm{~g} / 1$ glucose) was continuously gassed with $95 \% \mathrm{O}_{2}$ and $5 \% \mathrm{CO}_{2}$ (Figure 1). ${ }^{8-9}$ The nerves were perfused with 


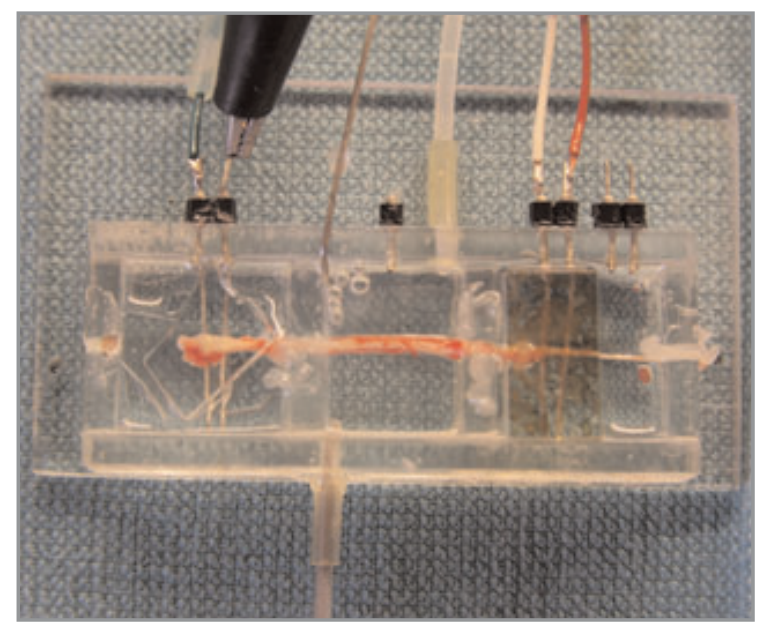

Figure 1. Pyrex bath

the Tyrode solution at a rate of $2 \mathrm{ml} / \mathrm{min}$ at a constant temperature of $37^{\circ} \mathrm{C}$ and $\mathrm{pH}$ of 7.4 throughout the experiments. Supramaximal stimulus pulses applied to the nerves $(0.1 \mathrm{~ms}$ in duration and $0.8 \mathrm{~Hz})$ were delivered by a 0811A Pulse Generator (Hewlett Packard, Melrose, MA, USA) through a Schwarzer AK1W161B Stimulus isolation unit (Schwarzer $\mathrm{GmbH}$, Munich, Germany). The changes in amplitude $(\mathrm{mV})$, and duration $(\mathrm{ms})$ of cAPs of nerves were measured for test and control nerves for a total of 60 min, while an intimate contact was established between the specimen and the nerve..$^{8-9}$ The time (ms) required for a stimulus to pass through electrodes was recorded and expressed as the signal transduction speed. The nerves of the control group were subjected to quantification of signal transduction speeds and changes in amplitude and duration of cAPs of the nerves. The nerve signals were digitized by a Biopac MP35 Data Acquisation System (Biopac Systems Inc., CA, USA) and were displayed in a computer through corresponding software (Biopac Student Lab Pro 3.6.6.; Biopac Systems Inc.) at a sample rate of $100 \mathrm{kHz}^{8-9}$

As an indication of the viability of the nerve, the cAP was evoked by the stimulating electrodes and recorded by the recording electrodes using standard electrophysiological methods. The minimal threshold required for evoking a cAP for each nerve was determined before testing with the prepared solutions. Prior to experiments, an approximate time of $60 \mathrm{~min}$ was required for the cAPs of the nerves to reach a steady state. During all experiments, the percentage amplitude of the cAPs versus time diagram was plotted. . $^{80-11}$

After the completion of each experiment, the tested nerve was discarded and a fresh nerve was used for the upcoming experiment. The first set of 6 sciatic nerves was used for control group and tested for 100 min at 10 min intervals. In the second group, the experiment was initiated with $50 \mu \mathrm{ABS}$ solution and the measurements were made for 60 minutes at 10 minute intervals. Then the bath was rinsed three times with fresh tyrode solution, after which the measurements were continued for another 60 minutes at 10 minute intervals using the same nerve. The same procedure was applied for $100 \mu \mathrm{l}, 250 \mu \mathrm{l}, 500 \mu \mathrm{l}$ and $1000 \mu \mathrm{l}$ ABS solution on different nerves.

Statistical Analysis: The overall differences among dose groups for all measured parameters were investigated at two time intervals (60 and $120 \mathrm{~min}$ ) by Kruskal-Wallis test. Pairwise differences were analyzed using Mann-Whitney $\mathrm{U}$ test, with Bonferroni correction for multiple comparisons. Overall type-I error level was set at 5\%. Clinically-significant differences with a $\mathrm{p}$ value less than 0.1 were also pointed out as differences close to the level of statistical significance.

\section{RESULTS}

At a concentration of $1000 \mu \mathrm{L}$, the ABS solution caused significant depression of the cAP voltage values $(p=0.054)$. The pairwise comparisons also showed that the only significant differences were between $1000 \mu \mathrm{L}$ and the rest of the solutions, but this effect was totally reversible after washing with tyrode solution at 120 min readings $(p=0.95)$. No significant difference exists among groups for any other parameter (depolarization, repolarization and excitation times) (Figures 2 and 3).

\section{DISCUSSION}

Dental surgery in patients with haemorrhagic diathesis represents a great clinical challenge regarding the bleeding and complicated infections. Patients who have bleeding disorders undergoing dental interventions can have postoperative excessive bleeding complications. ${ }^{1,12}$ ABS could be effectively used both 


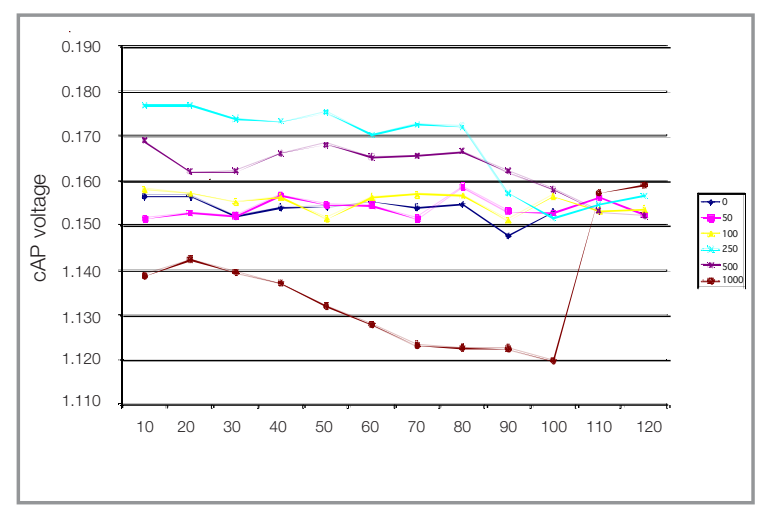

Figure 2. CAP voltage values. Significant decrease with 1000 $\mu \mathrm{L}$ ABS solution. After washing the specimens all groups shows smilar values.

in individuals with normal haemostatic parameters and in patients with deficient primary homeostasis and/or secondary homeostasis.

In rats pretreated with warfarin, ABS has been shown to provide a therapeutic potential for the management deficient primary homeostasis. ${ }^{13}$ The efficacy of ABS on superficial and deep skin lacerations and minor/moderate trauma injuries has also been demonstrated in a porcine bleeding model previously ${ }^{14}$ In the experimental burn injury model, Coban et al found ABS as effective as topical adrenaline on reducing excisional bleeding. ${ }^{15}$ Huri et al concluded, ABS as effective as other haemostatic (suturing) and licensed sealant agents (Glubran 2, FloSeal,and Celox) with comparable warm ischemia time and hemostasis time and better results in terms of histopathologic findings..$^{16}$ Further, a number of clinical case reports have demonstrated successful bleeding management by ABS applied topically over uncontrolled bleeding. ${ }^{17-18}$ Also tissue friendly characteristic of ABS was well demonstrated in articles..$^{1920}$ Ercetin et al, demonstrated the safety and efficacy of ABS in dental surgery with 25 patients' various dental problems. ${ }^{21}$ These findings suggest that ABS has a strong potential of usage in medical practice, particularly in dentistry.

The potential adverse effect of haemostatic agents on nerve tissue is a serious concern in clinical practice. Using the dog model, Zeltser et al. ${ }^{22}$ studied the functional and histological effects of topical haemostatic agent (human thrombin bbovine gelatine matrix) on prostatic neurovascular bundle. The investigators

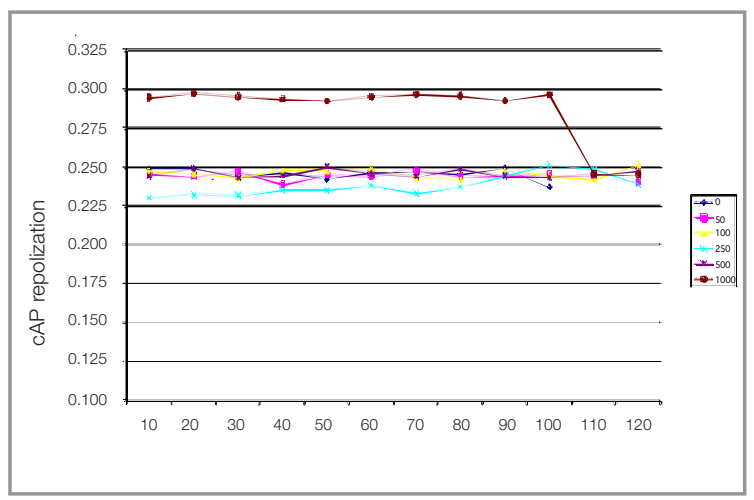

Figure 3. CAP repolization depending on time.

dissected bilateral neurovascular bundles to observe the potential adverse effects of the haemostatic agents on nerve tissue. Erectile function of the treatment side was normal after electrical stimulation. Histological examination showed giant cell reaction around the haemostatic agent granules and mild focal perineural edema. As a conclusion, they stated that bovine thrombin haemostatic agent did not have adverse effect on nerve conductance..$^{22}$

Kassam et al., studied the safety of a fibrin glue product (Tisseel ${ }^{\circledR}$ )applied directly on the brain parenchyma, cervical cord and C3-C6 spinal roots of 6 monkeys to determine if any underlying biochemical injury would occur on the tested neural tissue. They concluded that the fibrin glue product did not induce an apparent inflammatory response or abnormal neurophysiological or histological response over neural tissues ${ }^{23}$ Vries et al, reported similar results after utilizing a fibrin glue on the intracranial nerves of rats. The authors concluded that there was no additional brain damage, intracranial nerve damage or scar tissue formation. ${ }^{24}$

Contrary to those findings, Voormole et al. observed formation of polynucleated giant cells over oxidized cellulose and reactive cell growth throughout collagen fleece haemostatic agents when used as a haemostatic agent in neurosurgery in the rat. ${ }^{25}$ Alkan et al. reported reduced nerve conduction velocity and increased compound action potentials after administering oxidized regenerated cellulose in close proximity to the rat sciatic nerve. ${ }^{26}$ In another rat experiment, oxidized regenerated cellulose (Surgicel ${ }^{\circledR}$ ) 
blocked neural conduction in five of the eight experiments within two hours. ${ }^{27}$

In routine dental surgical procedures such as tooth extraction, the ABS solution may easily contact the nerve tissue. This study was conducted to evaluate the concentration-dependent effect of ABS over isolated nerve tissue. With increasing concentration, decreasing in cAP voltage values and increasing cAp repolarization values were observed. For the first 60 min, the only statistically significant decrease in cAP voltage was observed at $1000 \mu \mathrm{L}$ concentration. However, reversal of cAPs were observed after washing the specimens, indicating the transient effect of ABS on nerve conductance. Undoubtedly, histological examination of the test specimens may be helpful about determining the neural effects of $\mathrm{ABS}$ at the cellular level.

This study showed that the effect of ABS on nerve conductance is both concentration-dependent and reversible. Further studies should evaluate the neurotoxic effects of ABS over extended periods of contact with the nerve tissue. Provided that prolonged contact of ABS is not detrimental to nerve conductance, the clinical use of ABS on nerve-critical surgical sites may be advocated.

\section{REERENCES}

1. Garfunkel AA, Galili D, Findler M, et al. Bleeding tendency: a practical approach in dentistry. Compend Contin Educ Dent 20:836-838, 1999.

2. Lockhart PB, Gibson J, Pond SH, Leitch J. Dental management considerations for the patient with an acquired coagulopathy. Part 2: Coagulopathies from drugs. British Dental Journal 195: 495-500, 2003.

3. Miloro M. Peterson's Princinles of oral and Maxillofacial Surgery. In PE L (ed) Princibles of medicine, surgery and anesthesia. 2. edition. London, Hamilton, 2004: 10.

4. Israels S, Schwetz N, Boyar R, McNicol A. Bleeding disorders: characterization, dental considerations and management. J Can Dent Assoc 72: 827, 2006.

5. Mitchell R. An evaluation of bone healing in cavities in the jaws implanted with a collagen matrix. $\mathrm{Br} \mathrm{J}$ Oral Maxillofac Surg 30:180-182, 1992.

6. Mattsson T, Anderssen K, Koendell PA, Lindskog S. A Longitudinal Comparative Histometric Study of the $\mathrm{Bi}$ ocompatibility of 3 Local Hemostatic Agents. Int J Oral Max Surg 19: 47-50, 1990.
7. Goker H, Haznedaroglu IC, Ercetin S, et al. Haemostatic actions of the folkloric medicinal plant extract ankaferd blood Stopper (R). J Int Med Res 36: 163-170, 2008.

8. Cehreli MC, Onur MA, Sahin S. Effects of hydroxyapatite-coated and commercially pure titanium oral implant surfaces on compound nerve action potentials - A study on the rat sciatic nerve. Clin Oral Implan Res 14: 269-272, 2003.

9. Onur MA, Cehreli MC, Tas Z, Sahin S. Effects of machined/turned, TiO2-blasted and sandblasted/acid-etched titanium oral implant surfaces on nerve conduction: A study on isolated rat sciatic nerves. J Biomed Mater Res Part B 67B:772-778, 2003.

10. Onur MA, Cehreli ZC, Tasman F, Gumrukcuoglu A. Neurotoxic effects of fifth-generation dentin adhesives on rat sciatic nerve. J Endodont 27:676-678, 2001.

11. Cehreli ZC, Onur MA, Tasman F, et al. Effects of current and potential dental etchants on nerve compound action potentials. J Endodont 28:149-151, 2002.

12. Fraction X, Pommereuil M, Berthier AM, et al. Management options for dental extraction in hemophiliacs: A study of 55 extractions (2000-2002). Oral Surg Oral Med O 99: 270-275, 2005.

13. Cipil HS, Kosar A, Kaya A, et al. In Vivo Hemostatic Effect of the Medicinal Plant Extract Ankaferd Blood Stopper in Rats Pretreated With Warfarin. Clin Appl Thromb-Hem 15:270-276, 2009.

14. Bilgili $\mathrm{H}$, Kosar A, Kurt M, et al. Hemostatic efficacy of Ankaferd Blood Stopper in a swine bleeding model. Med Princ Pract 18: 165-169, 2009.

15. Coban YK, Ozerol E, Tanber K, et al. The homeostatic efficacy of ankaferd after excision of full thickness burns: a comparative experimental study in rats. Surg Sci 2: 16-21, 2011.

16. Huri E, Akgul KT, Yucel MO, et al. The second step in vitro trial of Ankaferd bloodstopper: Comparison with the other hemostatic agents. Turk J Med Sci 41:7-15, 2011.

17. Kurt M, Disibeyaz S, Akdogan M, et al. Endoscopic application of Ankaferd blood stopper as a novel experimental treatment modality for upper gastrointestinal bleeding: A case report. Am J Gastroenterol 103: 2156-2158, 2008.

18. Kurt M, Kacar S, Onal IK, et al. Ankaferd Blood Stopper as an effective adjunctive hemostatic agent for the management of life-threatening arterial bleeding of the digestive tract. Endoscopy 40 Suppl 2:E262, 2008.

19. Akgul T, Huri E, Ayyıldız A, Ustun H, Germiyanoglu C. Haemostatic and Histopathological Effects of Ankaferd Blood Stopper, on Penile Cavernosal Tissue in Rats. UHOD 19: 159-165, 2009.

20. Aktas A, Er N, Onur MA. Effects of Ankaferd Blood Stopper (R) on Vascular Response in Rat Carotid Artery. UHOD 20: 156-162, 2010.

21. Ercetin S, Haznedaroglu IC, Kurt M, et al. Safety and Efficacy of Ankaferd Blood Stopper in Dental Surgery. UHOD 20:1-5, 2010. 
22. Zeltser I, Dugi D, Gupta A, et al. Does Topical Haemostatic Agent Have an Adverse Effect on the Function of the Prostatic Neurovascular Bundle? Comment. J Urology 181: 2826-2826, 2009.

23. Kassam A, Nemoto E, Balzer J, et al. Effects of Tisseel fibrin glue on the central nervous system of nonhuman primates. Ear Nose Throat J 83: 246-248, 2004.

24. de Vries J, Menovsky T, van Gulik S, Wesseling P. Histological effects of fibrin glue on nervous tissue: a safety study in rats. Surg Neurol 57: 415-422, 2002.

25. Voormolen JH, Ringers J, Bots GT, et al. Hemostatic agents: brain tissue reaction and effectiveness. A comparative animal study using collagen fleece and oxidized cellulose. Neurosurgery 20: 702-709, 1987.

26. Alkan A, Inal S, Yildirim M, et al. The effects of hemostatic agents on peripheral nerve function: An experimental study. J Oral Maxillofac Surg 65: 630-634, 2007.

27. Loescher AR, Robinson PP. The effect of surgical medicaments on peripheral nerve function. $\mathrm{Br} \mathrm{J}$ Oral Maxillofac Surg 36: 327-332, 1998.

\section{Correspondence}

Dr. Alper AKTAŞ

Hacettepe Üniversitesi Diş Hekimliği Fakültesi

Oral Maksillofasiyal Cerrahi Bölümü

06100 Sinhiye

Ankara / TURKEY

Tel: (+90.312) 3052220

e-mail: alperaktas@gmail.com 